\title{
Influence of Differentiation Strategy on Performance of Deposit Taking Savings and Credit Cooperative Societies in Uasin Gishu County, Kenya
}

\author{
Mr. Peter Simotwo ${ }^{1} *$, Dr. Phelista Wangui Njeru ${ }^{1}$, Dr. Christine Jeptoo ${ }^{1} \&$ Dr. Erastus Thoronjo ${ }^{2}$ \\ 1.Scholar, School of Business and Economics, Mount Kenya University \\ 2.Senior Lecturer, School of Business and Economics, Mount Kenya University \\ * E-mail of the corresponding author: petersimotwo532@gmail.com
}

\begin{abstract}
Savings and Credit Co-operative Societies (SACCOs) in Kenya quite like any other commercial establishments encounter significant difficulties presented by ever-changing and intensely aggressive market conditions. Nevertheless, for SACCOs to contest confidently and remain relevant, they are obliged to recognize and follow relevant differentiation strategies. This study analyzed the influence of differentiation strategy on performance deposit-taking SACCOs in Uasin Gishu County Kenya. The study was anchored on Resource-Based View Theory and utilized a cross-sectional descriptive survey research design. Target population comprised 277 officials from the deposit-taking SACCOs. Yamane (1967) formula employed to determine expected sample size of 164 respondents. The research instrument adopted for data collection was a five-point Likert scale questionnaire. The reliability of the instruments was resolved through the internal consistency where Cronbach's Alpha correlation coefficient of 0.7 and above was considered acceptable. Data were descriptively analyzed using means and standard deviation, and inferentially by correlation and regression analysis. The study results indicated that differentiation strategy had explanatory power over performance of deposit taking SACCOs where it accounted for 61.3 percent of the variations $(\mathrm{R} 2=.613)$ hence the study rejected $\mathrm{H} 0_{1}$ and stated that the influence of differentiation strategy on performance deposit-taking SACCOs was statistically significant. Based on the study finding, the study concluded that differentiation strategies (innovation adoptions, brand image, and product packaging) had a significant influence on performance of deposit taking SACCOs. The study recommended that the deposit-taking SACCOs' management should embrace market research, innovations and creativity and adopt appropriate technologies and supportive resources.
\end{abstract}

Keywords: Differentiation Strategies, deposit-taking SACCOs’ performance, Uasin Gishu, Kenya

DOI: $10.7176 / \mathrm{EJBM} / 13-20-03$

Publication date:October $31^{\text {st }} 2021$

\section{Acknowledgement}

First, I am indebted to the Almighty God for giving me good health throughout my study. I wish to communicate my genuine appreciation to my principal supervisors, Dr. Phelista Wangui Njeru, Dr. Christine Jeptoo and Dr. Erastus Thoronjo for their professional direction, guidance, constant support, and friendly assistance during the development of this study. To my precious family, thank you for your constant prayers and financial support during my study period. May God bless you all.

\subsection{Background to the Study}

Today's cutthroat rivalry is the driving force describing why most organizations are putting a lot of effort to strategize on differentiation. Pearce and Robinson (2015) maintain that differentiation strategy is concerned with developing a place that possible clients see as unique based on special traits that meet that class of customers or a generic competitive strategy that creates a competitive edge with its product or service by having it "different" from other possible competitive products based on its features. This strategy entails being distinguished and different in processes that are adequately appreciated by consumers; differentiation strengthens competitive benefit by presenting customers as more dependable and less price-sensitive to a furnished product/service. It includes innovation that studies how marketing techniques, sales, and advertising activities are employed and on the other hand where innovation is cantered partially on characteristics of manufacturing products, performance, or quality (Hansen et al., 2015). Moreover, Allen and Helms (2006) stress the importance of differentiation in a company image that increases the sensitivity of the buying process for customers. Through this many researchers have recognized that business that select differentiation has competitive gain and yield better performance than rivals do (Allen and Helms, 2006; Teeratansirikool et al., 2013).

Businesses that lacks something distinctive and imitates others, loses their competitive benefit and are therefore likely to perform poorly than their rivals (Raduan, Jegak, Haslinda \& Alimin, 2009). To circumvent duplication by contending firms, firms ought to be inventive by working on new movements and thus remaining competitive. Hitt, Ireland, and Hoskisson (2007) proposes that organizations that follow differentiation strategy 
try to attain competitive gain by creating a product or service that is unique, hoping to create brand loyalty for their members and thus, price inelasticity on the part of the buyers. Barney (2013) says that though a company may have several basis of differentiation, at the end it is only a matter of customer perception. A prosperous product differentiation strategy will transfer products from competing essentially on price to fighting on non-price determinants, or promotional variables (Wanyama, 2009). Differentiation is a viable strategy to be utilized by SACCOs especially for earning above-average profits in an industry because it constitutes a justifiable ground for coping with the five competitive forces that shape the market (Porter, 2007). It renders insulation against competitive rivalry because of brand name descriptions by customers.

Differentiation strategy is described as a planned series of activities to differentiate products, commodities, and services that customers perceive to be distinct in key ways (McGee\& Sammut-Bonni, 2014). A differentiation strategy involves the development of product or service characteristics that are distinct from rivals', appealing to customers, and functional, as well as customer support and product quality. Differentiation entails providing services that are distinct from and more desirable than those of rivals (Putra, Sudarmiatin, \& Suharto, 2018). The goal of a differentiation strategy is for a company to be distinctive in the industry along some characteristics that purchasers highly appreciate (Pérez-Cabañer, González-Cruz \& Cruz-Ros, 2012). Customers must be somewhat price-insensitive for the differentiation approach to work. When product characteristics are considered, the costs of a differentiated product may be greater than the price of a generic, non-differentiated product. If a differentiation strategy is to be successful, customers must be ready to pay more than the marginal cost of introducing the differentiating feature (Porter \& Kramer, 2011).

\subsection{Statement of the Problem}

SACCOs play a crucial role in the mobilization of resources and therefore the sub-sector occupies a strategic position in the social-economic growth and the realization of the Kenya Vision 2030. SACCOs in Kenya quite like any other commercial establishments encounter significant difficulties presented by ever-changing and intensely aggressive market conditions. In order to accomplish their objectives, firms utilize several procedures of generic competitive strategies to aid them improve their performance and SACCOs are no exemption.

Deposits taking SACCOs have continued to face problems despite their significant contribution to the economy especially in the recent performance trends. SASRA (2017) supervision report showed a static membership share at 3.6 Million persons in 2017 as it was in 2016 and 2015. The dormant membership is an evidence of stagnation in growth rate. The distribution of the market share by way of the total assets held by deposit taking SACCOs remained the same in 2017 as it was in 2016 and 2015; the combined total assets portfolio declined from $35.02 \%$ in $2015,35.36 \%$ in 2016 to $32.38 \%$ in 2017 . The SACCOs paid an average $6.95 \%$ interest on members' deposits (savings) which was a marked decrease from the average rate of $9.7 \%$ paid in 2016 and $9.54 \%$ in 2015 which reflected a decrease from the average rate of $8.58 \%$ paid in $2015,8.4 \%$ paid in 2016 . Total deposits in 2017 stood at $12.4 \%, 11.3 \%$ and $12 \%$ respectively, compared to $14.8 \%, 15.3 \%$, and $14.8 \%$ respectively registered in 2016. It nevertheless remained a concern that the deposit taking SACCOs illustrated an uneven concentration of deposits within the arrangement.

Therefore, the applicability of the Porters generic strategies on performance of deposit taking SACCOs in Uasin Gishu County is yet to be empirically established a knowledge gap this research sought to lock. The researcher acknowledged also the need for empirical gaps to recognize a framework, which extends itself to strategic competitiveness. Methodological gaps were also recognized firmly that there was need for more objective indicators of performance, because it fell short in most of the previous studies. In order to promote growth of knowledge in this important area, the researcher purposed to study on the differentiation strategy and performance of deposit taking SACCOs in Uasin Gishu County, Kenya.

\subsection{Objective of the Study}

The main objective of study was to analyze the influence of differentiation strategy on performance of deposit taking SACCOs in Uasin Gishu County, Kenya.

\subsection{Hypotheses}

$\mathbf{H}_{01}$ : There is no statistically significant influence between differentiation strategy and performance of deposittaking SACCOs in Uasin Gishu County, Kenya

\subsection{Literature Review}

\subsubsection{Theoretical Framework}

The roots of Resource Based View (RBV) go back to Penrose (1959), who hinted that the possessions owned, disposed of, and handled by the organization are more valuable than industry composition. The name "resourcebased view" was invented much later by (Wernerfelt, 1984), who observed the company as a set of assets or supplies that are semi-permanently linked to the company. The theory explained that the organizations' source of 
competitiveness is found within the company's ability to manage its internal resources. Barney (2008) also made it clear that a company's resources are its fundamental source of competitive advantage and argued that a firm has the prospective to create sustained competitive advantage from resources that are valuable, rare, inimitable, and non-substitutable (VRIN). This theory highlights the advantages of being distinctive, and its basis for competitive benefit speculates in the size of the resources and the ability to realize the competitive gains it aims for better superior performance (Barney, 2011).

The proponents of this theory maintain that only the superior resources in the firm can benefit in accomplishing a sustainable competitive advantage. SACCOs should pursue to come up with resources that are imitable with time so that they can realize significant and long-term competitive advantage. RBV also claims that the competitive gains stem from the company's possessions and capability; indicates the organization's resources and how they are managed so that they are the central key part of the organization's competitive advantage and performance (Clegg et al., 2011).

In summary, RBV is the most widespread theory describing the notion of SCA. It is an introverting strategy looking for sources of competitive support inside the company in its assets and capabilities. Comparing to assets (which are tangible resource revenues), the capabilities are more complicated entities. This approach proposes to see the flourishing strategic performance of SACCOs as the outcome of SCA. Therefore, this theory is suitable in this study because, with the right identification and appropriation of generic competitive strategies, SACCOs will be in a situation to reveal their strength to perform or direct resources in such a way that opponents cannot duplicate them hence superior performance.

\subsubsection{Conceptual Framework}

The influence of differentiation strategy on performance of deposit taking SACCOs in Uasin Gishu County was the main objective of this study. The framework had differentiation strategy as the independent variable and performance of deposit taking SACCOs as the dependent variable as revealed in figure1.

\section{Independent Variable}

\section{Dependent Variable}

\begin{tabular}{|c|c|}
\hline Differentiation Strategy & Performance of DT-SACCOs \\
\hline -innovations Adoption & - Membership \\
\hline -Brand Image & - $\quad$ Profitability \\
\hline -Product Packaging & - Market Share \\
\hline
\end{tabular}

Figure 1: Conceptual Framework

Source: Primary Data

\subsection{Methodology and Design}

The study was both quantitative and qualitative by nature since the researcher intended to establish the extent to which differentiation strategy influence performance of deposit taking SACCOs. This study utilized crosssectional descriptive survey research design of deposit taking SACCOs. Cooper and Schindler (2014) argue that by adopting the descriptive survey design, the researcher was able to describe the variables of the study and develop predictive regression model for forecasting the dependent variable. This design has the benefit of containing current views or disciplines and presenting knowledge in a short amount of time, such as the interval expected for distributing the survey and gathering the information. This design affords a quantitative or numeric description of trends, attitudes, or feelings of a population by examining a sample of that population. From sample results, the researcher concludes or draws inferences to the group (Kotler \& Keller, 2011).

\subsection{Target Population}

The target population was 277 employees, which comprised of board of director, supervisory committee senior and middle management team from the branch network of deposit-taking SACCOs in Uasin Gishu County (Mwalimu National, Harambee, Kenya Police, Stima and Afya). The officials of these SACCOs were targeted because they were the ones who were conversant and constantly apply differentiation strategy for performance of deposit taking SACCOs in the society. The target population was as summarized in Table 1 
Table 1: Target Population

\begin{tabular}{lllllll}
\hline SACCOs & Mwalimu & Harambee & Kenya Police & Stima & Afya & Sub-total \\
\hline Board of Directors & 9 & 11 & 9 & 9 & 9 & $\mathbf{4 7}$ \\
Supervisory Committee & 3 & 3 & 3 & 3 & 3 & $\mathbf{1 5}$ \\
Senior Management & 17 & 21 & 12 & 11 & 11 & $\mathbf{7 2}$ \\
Middle Management & 35 & 35 & 26 & 28 & 19 & $\mathbf{1 4 3}$ \\
TOTAL & $\mathbf{6 4}$ & $\mathbf{7 0}$ & $\mathbf{5 0}$ & $\mathbf{5 1}$ & $\mathbf{4 2}$ & $\mathbf{2 7 7}$ \\
\hline
\end{tabular}

Source: Kenya Union of Savings and Credit Co-operatives 2021.

\subsection{Sampling Procedure and Techniques}

This study utilized stratified random sampling where five categories were selected to form strata. The researcher considered this method appropriate because it is administratively convenient and ensures inclusion of all targeted subgroups to be part of the sample (Saunders et. al., 2011). In determining the sample size, the study was informed by the formula suggested by Yamane (1967) which is expressed as:

$\mathrm{n}=\frac{N}{1+N\left(e^{2}\right)}$

Where; $\mathrm{n}$ is the sample size, $\mathrm{N}$ is the target population and e is the level of precision (specifically $\pm 5 \%$ precision at $95 \%$ confidence level).

Stratified method was employed in this study because the population has several managerial levels that were used as strata. Stratified sampling is necessary when the study needs to group people in heterogeneous groups to get a representative sample. This led to producing a sample size of 164 respondents as shown in Table 2.

Table 2: Sample Size

\begin{tabular}{lllllll}
\hline SACCOs & Mwalimu & Harambee & Kenya Police & Stima & Afya & Sub-total \\
\hline Board of Directors & 5 & 6 & 5 & 5 & 5 & $\mathbf{2 6}$ \\
Supervisory Committee & 2 & 2 & 2 & 3 & 2 & $\mathbf{1 1}$ \\
Senior Management & 10 & 12 & 7 & 7 & 6 & $\mathbf{4 2}$ \\
Middle Management & 21 & 21 & 16 & 16 & 11 & $\mathbf{8 5}$ \\
TOTAL & $\mathbf{3 8}$ & $\mathbf{4 1}$ & $\mathbf{3 0}$ & $\mathbf{3 1}$ & $\mathbf{2 4}$ & $\mathbf{1 6 4}$ \\
\hline
\end{tabular}

Source: Researcher, (2021)

\subsection{Proposed Data Analysis Techniques and Procedure}

Data generated sought to determine the influence of differentiation strategies (innovation adoptions, brand image, and product packaging) on performance of deposit-taking SACCOs. Since the independent variable (differentiation strategy) and the dependent variable (performance of deposit-taking SACCOs) were continuous, a Pearson correlation coefficient and linear regression model were utilized to probe the null hypothesis that there is no statistically compelling influence between differentiation strategy and performance of deposit-taking SACCOs. The resultant simple regression equation can be expressed as:

$\mathrm{PDTS}=\beta_{0}+\beta_{1} \mathrm{IA}+\beta_{2} \mathrm{BI}+\beta_{3} \mathrm{PP}+\varepsilon$.

Where:

PDTS $=$ Performance of Deposit-Taking SACCOs

$\beta_{0}=y$-Intercept; Constant

$\beta_{1}, \beta_{2}$, and $\beta_{3}=$ Beta or the Slope Coefficient

$\mathrm{IA}=$ Innovations Adoption

$\mathrm{BI}=$ Brand Image

$\mathrm{PP}=$ Product Packaging

$\varepsilon=$ Error Term

\subsection{Study Findings}

\subsubsection{Descriptive Statistics of the Study Variables}

The study collected data and measured on a 5-point Likert scale; $1=$ Strongly Disagree, $2=$ Disagree, $3=$ Undecided, 4= Agree, and 5= Strongly Agree. The results were presented as descriptive statistics in form of Mean (M) and Standard deviation (SD). The results then implied that; 1 to $1.8=$ Strongly Disagree, above 1.8 to $2.6=$ Disagree, above 2.6 to $3.4=$ Undecided, above 3.4 to $4.2=$ Agree, and above 4.2 to $5.0=$ Strongly Agree .

\subsubsection{Differentiation Strategy}

Differentiation strategy (innovation adoptions, brand image, and product packaging) was measured using 11 statements, the descriptive analysis of the constructs done utilizing mean, and standard deviation and the results displayed in Table 3. 
Table 3: Differentiation Strategy

\begin{tabular}{llll}
\hline & N & Mean & Std. Dev. \\
\hline Our SACCO offers products/services that are different from its competitors & 136 & 3.934 & .8925 \\
Our SACCO is creative and consistent in their product development & 136 & 3.984 & .9126 \\
$\begin{array}{l}\text { Departments in our SACCO are properly coordinated and efficient } \\
\text { Our SACCO offers unique products features that am/our institution/company is }\end{array}$ & 136 & 3.612 & .9327 \\
$\begin{array}{l}\text { willing to paying a higher price for } \\
\text { Our SACCO ensures that there is a close influence between the customers and }\end{array}$ & 136 & 3.936 & .9225 \\
the marketing team & 136 & 4.041 & .9546 \\
Our SACCO offers many product variations and a wide selection of products to & & & \\
cater for our SACCO's varied needs & 136 & 4.142 & .9228 \\
$\begin{array}{l}\text { Our SACCO ensures constant improvement and use of innovation to stay ahead } \\
\text { of the competitors }\end{array}$ & 136 & 3.679 & .9330 \\
Our SACCO is a strong brand in the market & 136 & 3.1364 & .9025 \\
Our SACCO constantly, identifies competencies and decides on how best to & 136 & 3.794 & .9329 \\
leverage them against opportunities & 136 & 3.843 & .9823 \\
Our SACCO constantly invents ways to create value for customers & 136 & 3.826 & .9288 \\
Our SACCO premises are well equipped with modern facilities & &
\end{tabular}
Source: Field Data, 2021

The statements that 'our SACCO offers many product variations and a wide selection of products to cater for our SACCO's varied needs and our SACCO ensures that there is a close influence between the customers and the marketing team had the highest mean score with 4.142 and 4.041 with standard deviation of .9228 and .9546 respectively. The study reported the lowest mean score by the statements departments in our SACCO are properly coordinated and efficient and our SACCO ensures constant improvement and use of innovation to stay ahead of the competitors 3.612 and 3.679 respectively and the rest of the statements reported relatively moderate mean scores.

\subsubsection{Performance of Deposit Taking SACCOs}

Performance of deposit taking SACCOs was measured using eight statements. Descriptive statistics, which involved mean and standard deviation, were jointly employed to summarize the responses as presented in Table 4 Table 2: Performance of Deposit Taking SACCOs

\begin{tabular}{lllc}
\hline & $\mathrm{N}$ & Mean & Std. Dev. \\
\hline $\begin{array}{l}\text { Our SACCO market share is relatively higher than other SACCOs in the } \\
\text { county. }\end{array}$ & 136 & 3.862 & .9069 \\
Our SACCO enjoys higher profitability margin than its competitors & 136 & 3.764 & .8981 \\
Our SACCOs delights in improved employees productivity than its rivals & 136 & 3.892 & .13681 \\
Our SACCOs membership has been on increase for the last three years. & 136 & 3.843 & .9806 \\
Our SACCOs enjoys operational efficiency than its contestants & 136 & 3.856 & .9881 \\
Our SACCO enjoys improved customer satisfaction than its competitors & 136 & 3.866 & .9024 \\
Our SACCO enjoys a larger customer base than its competitors & 136 & 3.727 & .8957 \\
There is consistent development of new products and services in our SACCOs & & & .9270 \\
because of improved customer retention. & & 3.819 &
\end{tabular}
Source: Field Data, 2021

The respondents indicated that their SACCO market share was higher than other SACCOs in the county were $(\mathrm{M}=3.862 ; \mathrm{SD}=0.9069)$, and that their SACCOs highly enjoyed higher profitability margin than their competitors $(\mathrm{M}=3.764 ; \mathrm{SD}=0.8981)$. They indicated that their SACCOs highly delighted in improved employees' productivity than their rivals $(\mathrm{M}=3.892$; $\mathrm{SD}=0.13681)$ and that their SACCOs membership had been on high increase for the previous four years $(\mathrm{M}=3.843$; $\mathrm{SD}=0.9806)$. It was shown that their SACCOs highly enjoyed operational efficiency than its contestants $(\mathrm{M}=3.856 ; \mathrm{SD}=0.9881)$ while their SACCO highly enjoyed improved customer satisfaction than their competitors $(\mathrm{M}=3.866$; $\mathrm{SD}=0.9024)$ as the SACCO highly enjoyed a larger customer base than their competitors $(\mathrm{M}=3.727 ; \mathrm{SD}=0.8957)$ and that there was highly consistent development of new products and services in their SACCOs because of improved customer retention. $(\mathrm{M}=3.819 ; \mathrm{SD}=0.9270)$.

\subsection{Correlation Analysis}

To determine the influence of differentiation strategy on performance of deposit-taking SACCOs, the study correlated the indicators of differentiation strategy (innovation adoptions, brand image, and product packaging) with the performance of deposit taking SACCOs and the results presented in Table 6. 
Table 6: Differentiation Strategy and Performance of Deposit Taking SACCOs

\begin{tabular}{|c|c|c|c|c|c|}
\hline & & 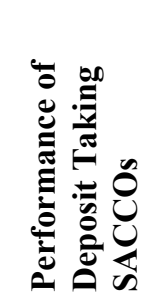 & 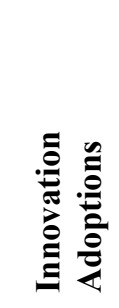 & 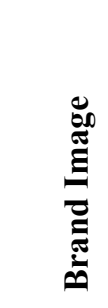 & 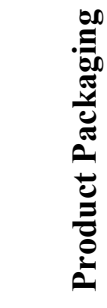 \\
\hline $\begin{array}{l}\text { Performance of Deposit Taking } \\
\text { SACCOs }\end{array}$ & Pearson Correlation & 1 & & & \\
\hline \multirow[t]{3}{*}{ Innovation Adoptions } & Pearson Correlation & $.523 *$ & 1 & & \\
\hline & Sig. (2-tailed) & .000 & & & \\
\hline & $\mathrm{N}$ & 136 & & & \\
\hline \multirow[t]{3}{*}{ Brand Image } & Pearson Correlation & $.484^{* *}$ & $.628 *$ & 1 & \\
\hline & Sig. (2-tailed) & .000 & .000 & & \\
\hline & $\mathrm{N}$ & 136 & 136 & & \\
\hline \multirow[t]{3}{*}{ Product Packaging } & Pearson Correlation & $.603 *$ & $.485 * *$ & $.536^{*}$ & 1 \\
\hline & Sig. (2-tailed) & .000 & .000 & .000 & \\
\hline & $\mathrm{N}$ & 136 & 136 & 136 & \\
\hline
\end{tabular}

*. Correlation is significant at the 0.05 level (2-tailed).

**. Correlation is significant at the 0.01 level (2-tailed).

Source: Field Data, 2021

The study outcome demonstrated that product packaging had the highest correlation with performance of deposit taking SACCOs $(\mathrm{r}=.603, \mathrm{p}<.05)$. On the other hand, the association between innovation adoptions and performance of deposit taking SACCOs $(\mathrm{r}=.523, \mathrm{p}<.05)$ and the lowest and positive association was reported between brand image and performance of deposit taking SACCOs $(r=.484, p<.05)$. All the indicators of differentiation strategy (innovation adoptions, brand image, and product packaging) had statistically significant positive correlation amongst themselves with the highest correlation reported between innovation adoptions and brand image $(r=.628, \mathrm{p}<.05)$. This has the implication that they were all moving in the same direction.

\subsection{Regression Analysis and Hypotheses Testing}

The study objective was to determine the influence of differentiation strategy on performance of deposit-taking SACCOs. The objective null hypothesis stated as:

Ho2: There is no statistically significant influence between differentiation strategy and performance of deposit-taking SACCOs in Uasin Gishu County, Kenya

in order to determine the influence of differentiation strategy (innovation adoptions, brand image, and product packaging) on performance of deposit-taking SACCOs, the mean scores of differentiation strategy were regressed on aggregate mean score of performance of deposit-taking SACCOs indicators and the relevant study outcomes shown in tables 7, 8 and 9

Table 7: Regression Results for Differentiation Strategy and Performance of Deposit-Taking SACCOs Model Summary

\begin{tabular}{lllll}
\hline Model & R & R Square & Adjusted R Square & Std. Error of the Estimate \\
\hline 1 & $.783^{\mathrm{a}}$ & .613 & .586 & .70768 \\
\hline
\end{tabular}

a. Predictors: (Constant), product packaging, Brand Image, Innovation's adoption

Table 8: ANOVA Results for Differentiation Strategy and Performance of Deposit-Taking SACCOs

\begin{tabular}{lllllll}
\multicolumn{7}{c}{ ANOVA $^{\mathbf{a}}$} \\
\hline Model & & Sum of Squares & Df & Mean Square & F & Sig. \\
\hline \multirow{2}{*}{1} & Regression & 6.457 & 3 & 2.152 & 69.430 & $.000^{\mathrm{b}}$ \\
& Residual & 4.096 & 132 & .031 & & \\
& Total & 10.553 & 135 & & & \\
\hline
\end{tabular}

a. Dependent Variable: Performance of Deposit-Taking SACCOs

b. Predictors: (Constant), Product Packaging, Brand Image, Innovation's Adoption 
Table 9: Results for Differentiation Strategy and Performance of Deposit Taking SACCOs

\begin{tabular}{|c|c|c|c|c|c|c|}
\hline & & & & & & \\
\hline \multirow[t]{2}{*}{ Model } & & \multicolumn{2}{|c|}{$\begin{array}{l}\text { Unstandardized } \\
\text { Coefficients }\end{array}$} & \multirow{2}{*}{$\begin{array}{l}\text { Standardized } \\
\text { Coefficients } \\
\text { Beta }\end{array}$} & \multirow[t]{2}{*}{$\mathbf{T}$} & \multirow[t]{2}{*}{ Sig. } \\
\hline & & B & Std. Error & & & \\
\hline \multirow{4}{*}{1} & (Constant) & 5.835 & 1.149 & & 5.079 & .000 \\
\hline & Innovation Adoptions & .521 & .284 & .583 & 1.836 & .000 \\
\hline & Brand Image & .486 & .307 & 682 & 1.583 & .001 \\
\hline & Product Packaging & .432 & .324 & .478 & 1.333 & .000 \\
\hline
\end{tabular}

Dependent Variable: Performance of Deposit Taking SACCOs

Source: Field Data, 2021

Model summary (Table 7) demonstrated that differentiation strategy (innovations adoption, product packaging, and continuous improvement) had a positive association with performance of deposit-taking SACCOs $(\mathrm{R}=.783)$. Differentiation strategy (innovations adoption, product packaging, and continuous improvement) had explanatory power over performance of deposit-taking SACCOs since it accounts for 61.3 percent of performance of deposit-taking SACCOs change (R square $=.613$ ). The study result is in concurrence with Marangu, Mwiti and Thoronjo (2017) who conducted a study on the influence of differentiation strategy on the organizations' performance of sugar firms in Kenya. The study employed descriptive cross-sectional research design to be capable to attain its objective. The research covered all the sugar firms in Kenya with a target population of 190 manage and a sample size of 127 of them. Product differentiation strategy had illustrative authority over organizations' competitiveness of sugar firms' because it accounts for 41.3 percent of organizations' competitiveness of sugar firms' change (R square $=.413$ ).

The ANOVA (Table 8) outcomes exhibited that the influence of differentiation strategy (innovations adoption, brand image and product packaging) on performance of deposit-taking SACCOs was statistically significant since $\mathrm{p}$-value $<.05(\mathrm{p}-$ value $=.000)$. An F- value of 69.430 showed that the general model was important and could significantly predict the adjustment in performance of deposit-taking SACCOs in Uasin Gishu County. The coefficients results (Table 9) exposed a statistically significant positive influence of differentiation strategy (innovation adoptions, brand image, and product packaging) on performance of deposit taking SACCOs ( $\beta$ $=.521, .486, .432$ respectively). From the study conclusions, the resultant simple regression equation can be articulated as:

$\mathrm{PDTS}=5.835+.521 \mathrm{IA}+.486 \mathrm{BI}+.432 \mathrm{PP}+\varepsilon$.

Where:

PDTS $=$ Performance of Deposit-Taking SACCOs

5. $835=$ y-Intercept; Constant

$.521, .486, .432=$ Beta or the Slope Coefficient

$\mathrm{IA}=$ Innovations Adoption

$\mathrm{BI}=$ Brand Image

$\mathrm{PP}=$ Product Packaging

$\varepsilon=$ Error Term

This means that one standard deviance upgrading in innovations adoption, brand image and product packaging would raise level of performance of deposit-taking SACCOs by a factor of approximately .521, .486 and .432 respectively.

\subsection{Discussion on the Study Results}

The outcome of the study confirmed that differentiation strategy had a positive influence with performance of deposit taking SACCOs $(\mathrm{R}=.783)$. Differentiation strategy (innovation adoptions, brand image, product packaging) explained the variability of performance of deposit taking SACCOs because it accounted for 61.3 percent of its change $(\mathrm{R}$ square $=.613)$. This critically refuted the null hypothesis that differentiation strategy has no significant influence on performance of deposit taking SACCOs in Uasin Gishu County.

The study result is in concurrence with Marangu, Mwiti and Thoronjo (2017) who conducted a study on the influence of differentiation strategy on the performance of deposit taking SACCOs of sugar firms in Kenya. The study employed descriptive cross-sectional research design to be able to achieve its objective. The study covered all the sugar firms in Kenya with a target population of 190 manage and a sample size of one 127 of them. Product differentiation strategy had explanatory power over organizations' competitiveness of sugar firms' because it accounts for 41.3 percent of organizations' competitiveness of sugar firms' change (R square $=.413$ ). The research concluded that differentiation strategy had a significant influence on the organizations' competitiveness of the sugar firms. The study recommended that sugar firms' management should increase the usage of differentiation strategy in an effort to achieve more organizations' competitiveness. 


\subsection{Summary of the Findings}

The study correlated the indicators of differentiation strategy (product innovations, brand image and product packaging) with the performance of deposit taking SACCOs in Uasin Gishu County. All the indicators of differentiation strategy (product innovations, brand image and product packaging) had statistically significant positive correlation amongst themselves with the highest correlation reported between product innovations and brand image $(\mathrm{p}<.05)$.

\subsection{Conclusion}

The study concludes that differentiation strategy has significantly positive influence on performance of deposittaking SACCOs in a broad market $(\beta=.521, .486, .432$ respectively). The differentiation strategy, one of Porter's key business strategies allow concentrating efforts on creating a distinctive product or service using brand image, innovativeness, product quality, and firm reputation while pursuing improved performance.

\subsection{Recommendation}

From the study, the findings indicated that differentiation strategy has a significant influence on SACCO's performance. The investigation thus advises that SACCO authority should develop and sustain innovativeness, creativeness, and organizational training within the deposit-taking SACCOs to enhance performance of deposit taking SACCOs. The desired features should be incorporated into the product to encourage member preference for the product and even pay a premium price. It also suggests that SACCOs applying the differentiation strategy should contemplate on spending in and growing such situations that are distinct and which members will notice. Besides, what makes an organization unusual and competitors cannot easily imitate.

\section{References}

Allen, R., \& Helms, M. (2006). Methods of Inclusion and Application Use in Manufacturing Techniques. Business Process Management, 12 (4), 433-454.

Barney, J. B., \& Hesterly, W. (2013). Management and Competitive Competition: Tips and Issues. Mount Garri, Clegg, S., Carter, S., Koruberger, K. \& Schweitzer, J. (2011). Strategy Theory and Practice. Los Angeles: SAGE Publications.

Cooper, C.R., \& Schindler, P.S., (2014). Commercial Research Methods (December 12). Boston: McGraw-Hill World Edition.

Hansen, E., Nybakk, E., \& Panwar, R. (2015). Known Competitive Skills Compared To Hybrids in the Forestry Industry: Performance Results. Council and Economic Policy, 54, 51-57.

Knott, A.M. (2003). Various Developments and New Developments. Journal Management System, 24 (8), $687-$ 705.

Marangu, W., Mwiti, E., \& Thoronjo, E. (2017): Analysis of Differentiation Strategy Influence on Organizations' Competitiveness of Sugar Firms in Kenya: European Journal of Business and Management.

McGee, J. \& Sammut-Bonni, T. (2014). Differentiation strategies. In book: Wiley Encyclopedia of Management 3. ed.) Strategic Management (pp.3) John Wiley \& Sons Editors:

O'regan, N., Kluth, C. \& Parnell, J. (2011). Loss of Skill Groups as a Motivation for Strong Performance. Studies from the British Plastic Institute. The Process of Change. 20, 111-26.

Pearce, J. \& Robinson, R. (2016). Translation Management: Creative, Creative and Management, 10th Ed, New York; McGraw Hill.

Penrose, E. (1959). Strong Growth. Wiley: New York.

Pérez-Cabañero, C., González-Cruz, T., and Cruz-Ros, S. (2012). Do family SME managers value marketing capabilities' contribution to firm performance? Marketing Intelligence \& Planning, 30(2), 116-142

Pertusa-Ortega, E., Molina-Azorín, J., \& Claver-Cortés, E. (2007). Strong, Cohesive or 'Sticky'? Evaluate and Analyze Their Impact on Consistent Performance: Annual Conference of the European Management University. Paris, 16-19 May 2007.

Porter M.E., (2010); .Competition Committee: Competition and Competitive Analysis, Media, New York

Porter, M. (2012). Process in a Difficult World: Creating Value. Porter India Boston, Ma / New Delhi,

Porter, M.E., \& Kramer, M.R. (2011). Creating shared value. Harvard business review, 89(1/2), 62-77.

Putra, Y. S., Sudarmiatin, \& Suharto, (2018). Analysis of Differentiation Strategies to Create Competitive Advantage in Facing Global Markets. International Research Conference on Economics and Business. KnE Social Sciences, 254-269. DOI 10.18502/kss.v3i3.1888

Teng, B.S., Cummings, J.L. (2002). Business Is the Management of Human and Mental Resources. School Director, 18 (2), 81-91.

Wanyama, F. O. (2009). Survival of the Best: Kenya Coordinating Committee. Coop Africa Working 10 Papers, Dar Es Salaam, Tanzania: Global Working Group. 